\title{
Molecular Cloning of Clostridium thermocellum DNA and the Expression of Further Novel Endo- $\beta$-1,4-glucanase Genes in Escherichia coli
}

\author{
By MAREK P. M. ROMANIEC, NEVILLE G. CLARKE \\ AND GEOFFREY P. HAZLEWOOD* \\ Department of Biochemistry, AFRC Institute of Animal Physiology and Genetics Research, \\ Babraham, Cambridge CB2 4AT, UK
}

(Received 27 October 1986; revised 29 December 1986)

\begin{abstract}
Sau3A fragments of Clostridium thermocellum (NCIB 10682) DNA were ligated into the BamHI site of pBR322 and expressed in Escherichia coli $\mathrm{HB} 101$ and a $\mathrm{Lac}^{-}$mutant thereof. Twentyeight clones with carboxymethylcellulase (CMCase) activity were selected from two libraries by means of the Congo Red plate assay. Restriction enzyme analysis indicated that the CMCase ${ }^{+}$ clones contained a total of 13 unique DNA inserts. Hybridization of recombinant plasmids with chromosomal DNA confirmed the physical maps in all but one case and was further used to demonstrate the absence of homology between the HindIII restriction fragments of similar size which occurred in many of the clones. Without exception, CMCase ${ }^{+} E$. coli clones expressed endoglucanase activity, but differed with respect to the amount and nature of the enzyme activity produced; additionally, some clones had exoglucanase activity which, in at least one case, was not attributable to the production of a second enzyme. For a few selected clones, the partially purified CMCase was analysed by electrophoresis. A temperature profile characteristic of a thermostable enzyme was demonstrated for the endoglucanase of one of the most active clones. Based on the evidence presented here, it is probable that the 13 unique DNA fragments described do not contain any of the $C$. thermocellum endoglucanase genes previously cloned.
\end{abstract}

\section{INTRODUCTION}

Micro-organisms able to break down cellulose have great economic potential for increasing the utilization of renewable plant biomass as animal feed and for the production of fuels and chemicals by fermentation. Thermophilic bacteria are of particular interest in this respect, both in their own right, and as a source of desirable genes encoding highly active thermostable proteins for genetic constructions in mesophiles (Sonnleitner, 1983). Some 100 species of bacteria and fungi are known to produce cellulases (Ljungdahl \& Eriksson, 1985) but comparatively little information is available regarding the biochemistry and genetic regulation of these important enzymes.

The presence of thermostable cellulolytic activity capable of completely degrading crystalline cellulose (Johnson et al., 1982) has generated considerable interest in the anaerobic thermophile Clostridium thermocellum. The activity resides in a complex (the cellulosome) which is secreted into the culture supernatant during growth in batch culture and is composed of at least 14 polypeptides, having endoglucanase (1,4- $\beta$-D-glucan 4-glucanohydrolase, EC 3.2.1.4) and exoglucanase (cellobiohydrolase; 1,4- $\beta$-D-glucan cellobiohydrolase, EC 3.2.1.91) activities, and includes a $210 \mathrm{kDa}$ non-enzymic cellulose-binding factor (Lamed et al., $1983 a, b)$.

The molecular mass of the complex is commonly quoted as $2.1 \mathrm{MDa}$ but values calculated from electron micrographs of cellulosomes varied from 4 to $102 \mathrm{MDa}$, depending on the degree

Abbreviations: CMC, carboxymethylcellulose: CMCase, carboxymethylcellulase; DS, degree of substitution; MUC, 4-methylumbelliferyl $\beta$-D-cellobioside; MUG, 4-methylumbelliferyl $\beta$-D-glucoside. 
of dissociation of the complex (Coughlan et al., 1985). A recent ultrastructural study has confirmed the existence of large extracellular complexes in $C$. thermocellum and has also provided evidence for the likely mechanism of cellulolysis (Bayer \& Lamed, 1986). Biochemical analysis of the cellulosome has achieved some success through the purification and characterization of two endoglucanases with molecular sizes of $56 \mathrm{kDa}$ (Petre et al., 1981) and around $90 \mathrm{kDa}(\mathrm{Ng} \&$ Zeikus, 1981). The objective of complementary genetic studies has been to dissect and characterize the cellulase complex by cloning and expressing cellulase-encoding genes in a suitable host. To date, cloning and characterization of both the genes and their products has been reported for the $c e l A, c e l B$, celC and celD genes encoding different endoglucanase activities (Beguin et al., 1983; Cornet et al., 1983a, $b$; Schwarz et al., 1986; Petre et al., 1986; Joliff et al., 1986b); more recently, the celA, celB and celD genes have been sequenced (Beguin et al., 1985; Grepinet \& Beguin, 1986; Joliff et al., 1986a) and mRNA encoding endoglucanase A has been mapped (Beguin et al., 1986). Endoglucanase D, overproduced in Escherichia coli JM101, has been crystallized and studied by X-ray diffraction (Joliff et al., 1986c).

The different cloning approaches employed by two independent groups have resulted in further apparently novel $C$. thermocellum clones expressing largely uncharacterized endoglucanase activity (eight clones), $\beta$-glucosidase activity (two) and putative cellobiohydrolase activity (three) (Millet et al., 1985; Schwarz et al., 1985).

At present, a number of questions remain unanswered. (1) Are distinct and different genes present for each of the many cellulases shown to be produced by $C$. thermocellum in culture, and is their expression co-ordinately controlled? (2) Is cellobiohydrolase activity in $C$. thermocellum encoded by a separate gene or is it a property of certain endoglucanases? (3) Is the multiplicity of endoglucanase genes a consequence of gene reiteration? In order to address these questions, we have constructed genomic libraries from $C$. thermocellum and, in common with others, have found clones with carboxymethylcellulase activity $\left(\mathrm{CMCase}^{+}\right)$occurring at high frequency. The clones have been characterized with respect to the level of activity expressed in $E$. coli and their substrate specificity, and after restriction enzyme analysis and Southern hybridization of the cloned DNA fragments, it appears that a further 13 unique clones with endoglucanase or both endoglucanase and cellobiohydrolase activities have been found.

\section{METHODS}

Bacterial strains and media. For the isolation of DNA, C. thermocellum NCIB 10682 was cultured anaerobically in CM3 medium (Weimer \& Zeikus, 1977). Basal medium ( $75 \mathrm{ml}$ volumes) adjusted to pH 7.8 with $\mathrm{NaOH}$ and containing, per litre, $\left(\mathrm{NH}_{4}\right)_{2} \mathrm{SO}_{4}(1.3 \mathrm{~g}), \mathrm{K}_{2} \mathrm{HPO}_{4} .3 \mathrm{H}_{2} \mathrm{O}(2.9 \mathrm{~g}), \mathrm{KH}_{2} \mathrm{PO}_{4}(1.5 \mathrm{~g}), \mathrm{MgCl}_{2} .6 \mathrm{H}_{2} \mathrm{O}(1.0 \mathrm{~g})$, $\mathrm{CaCl}_{2}(0.15 \mathrm{~g}), \mathrm{FeSO}_{4}(1.25 \mathrm{mg})$, yeast extract $(2.0 \mathrm{~g})$, resazurin $(2 \mathrm{mg})$, cellobiose $(2.0 \mathrm{~g})$ and carboxymethylcellulose (CMC, sodium salt, low viscosity, DS >0.4, BDH) $(2.0 \mathrm{~g})$, was autoclaved $\left(121^{\circ} \mathrm{C} ; 15 \mathrm{~min}\right)$, gassed with $\mathrm{N}_{2}$ and, after the addition of filter-sterilized reducing solution $(5 \%, \mathrm{v} / \mathrm{v})$ containing $\left(\mathrm{g}^{-1}\right)$ cysteine hydrochloride (10.0) and $\mathrm{NaHCO}_{3}(100 \cdot 0)$, was equilibrated with $\mathrm{O}_{2}$-free $\mathrm{CO}_{2}$. Freshly-prepared medium was inoculated ( $1 \%$, $\mathrm{v} / \mathrm{v}$ ) with a $2 \mathrm{~d}$ culture of $C$. thermocellum in the same medium and the culture bottle, with a slightly loosened cap, was placed in an anaerobe jar which was flushed three times with $\mathrm{O}_{2}$-free $\mathrm{CO}_{2}$ before being incubated at $60^{\circ} \mathrm{C}$ for 2-5 d. E. coli $\mathrm{HB} 101$ and E. coli $\mathrm{MR} 65$ were cultured overnight at $37^{\circ} \mathrm{C}$ in Luria broth (LB) adjusted to pH 7.5 with $\mathrm{NaOH}$ and containing, per litre, tryptone $(10.0 \mathrm{~g})$, yeast extract $(5.0 \mathrm{~g})$ and sodium chloride $(10.0 \mathrm{~g})$. Agar $(1.5 \%$, $\mathrm{w} / \mathrm{v})$ and filter-sterilized ampicillin $\left(50 \mu \mathrm{g} \mathrm{ml}^{-1}\right)$ were added as required.

Isolation of DNA. Total DNA from $C$. thermocellum cultured in CM3 medium was isolated according to the method of Marmur (1961), modified to include treatment with proteinase $\left.\mathrm{K}(1 \mathrm{mg} \mathrm{ml})^{-1} ; \mathrm{BRL}\right)$ and RNAase (100 $\mu \mathrm{g} \mathrm{ml}^{-1}$; type II-A; Sigma). Large-scale preparations of plasmid DNA were made from $E$. coli HB101 by alkaline lysis (Maniatis et al., 1982). The method of Birnboim \& Doly (1979) was used for small-scale extraction and rapid screening of plasmid-containing clones.

In vitro genetic recombination. Purified pBR322 DNA $(75 \mu \mathrm{g})$ in a total volume of $300 \mu \mathrm{l}$ was linearized by incubating for $1 \mathrm{~h}$ at $37^{\circ} \mathrm{C}$ with $\mathrm{BamHI}(100 \mathrm{U})$ under the conditions recommended by the enzyme supplier. Calf intestinal phosphatase (Boehringer Mannheim) was added to the reaction mixture at a final concentration of $0.02 \mathrm{U}(\mu \mathrm{g} \mathrm{DNA})^{-1}$. The linearized plasmid DNA was washed twice with phenol/chloroform/isoamyl alcohol $(25: 24: 1$, by vol.), twice with chloroform/isoamyl alcohol $(24: 1, v / v)$ and precipitated with ethanol before resuspending in $10 \mathrm{~mm}$-Tris/ $\mathrm{HCl}, 1 \mathrm{~mm}$-EDTA (TE buffer), $\mathrm{pH} \mathrm{7.6.}$ 
For the construction of genomic library 1, C. thermocellum DNA was partially digested with Sau3A [0.07 $\mathrm{U}(\mu \mathrm{g} \mathrm{DNA})^{-1}$ ] for $1 \mathrm{~h}$ at $37^{\circ} \mathrm{C}$ and, after horizontal agarose gel electrophoresis in borate buffer (Maniatis $e t$ al., 1982), fragments in the 4-9 kbp size range were recovered by electroelution. For genomic library 2 , digestion of chromosomal DNA was carried out under similar conditions in four tubes, but the Sau3A concentration was varied from 0.001 to $0.025 \mathrm{U}(\mu \mathrm{g} \mathrm{DNA})^{-1}$. Digests were pooled and DNA fragments 4-9 kbp in size were recovered from a gel by electroelution.

For both libraries, ligation of $C$. thermocellum DNA fragments $(0.25 \mu \mathrm{g})$ to linearized vector $(0.5 \mu \mathrm{g})$ was carried out at $12.5^{\circ} \mathrm{C}$ for $36 \mathrm{~h}$ under the buffering conditions specified for T4 DNA ligase by the supplier.

The ligation mixture for the first library was transformed into $E$. coli $\mathrm{HB101}$, and for the second library into $E$. coli MR65, a $\mathrm{Lac}^{-}$mutant of strain HB101 generated in this laboratory to facilitate the selection of clones expressing $\beta$-glucosidase activity from the $C$. thermocellum genomic library. Recombinant plasmid was transformed into both $E$. coli strains with an efficiency of about $3 \times 10^{3}$ ( $\mu$ g total DNA) ${ }^{-1}$. Competent cells were prepared using a modified $\mathrm{CaCl}_{2}$ procedure (Cohen et al., 1973) and stored at $-70^{\circ} \mathrm{C}$ until required. Transformants were initially plated on LB medium containing ampicillin $\left(50 \mu \mathrm{g} \mathrm{m}^{-1}\right)$ and the frequency of occurrence of the $\mathrm{Ap}^{\mathrm{R}} \mathrm{Tc}^{\mathrm{S}}$ phenotype ( $>95 \%$ of clones) was subsequently determined and taken as a measure of the rate of insertion. The presence of recombinant plasmid in mini-preparations from $\mathrm{Ap}^{\mathrm{R}} \mathrm{Tc}^{\mathrm{S}}$ clones was confirmed by gel electrophoresis after treatment of extracted plasmid DNA with EcoRI under conditions specified by the enzyme supplier.

For the selection of $\mathrm{CMCase}^{+}$clones, transformants were replicated on $\mathrm{LB}$ with ampicillin $\left(50 \mu \mathrm{g} \mathrm{m}^{-1}\right)$ using sterile nitrocellulose filters (Millipore HATF085), and after overnight incubation at $37^{\circ} \mathrm{C}$, colonies were screened by means of the Congo Red plate assay as described below.

Restriction digests. Single and double enzyme digestion of recombinant plasmids extracted from $\mathrm{CMCase}^{+}$ clones were carried out using the restriction endonucleases BamHI, HindIII, PstI, EcoRI, BglII and SalI. Incubations were of $16 \mathrm{~h}$ duration with an enzyme concentration of $1-3 \mathrm{U}(\mu \mathrm{g} \mathrm{DNA})^{-1}$. Conditions used were those specified by the supplier of each enzyme. DNA fragments were fractionated by electrophoresis in $1 \%(w / v)$ agarose gels and their sizes estimated by reference to the migration of standards.

Southern blot hybridization. Chromosomal DNA from $C$. thermocellum or recombinant plasmid DNA from $\mathrm{CMCase}^{+} E$. coli clones was digested with restriction endonucleases as required and fractionated on $1 \%(\mathrm{w} / \mathrm{v})$ agarose gels. DNA was then blotted on Hybond N (Amersham). ${ }^{32}$ P-labelled DNA probes (recombinant plasmids or restriction fragments therefrom) were prepared by nick translation (Rigby et al., 1977) using $\alpha-{ }^{32}$ P-dCTP (Amersham) and hybridization was carried out as described by Southern (1975). Autoradiography was performed at $-70^{\circ} \mathrm{C}$ using Kodak X-S1 film and two intensifying screens.

Preparation of cell-free extracts. $\mathrm{CMCase}^{+} E$. coli clones containing recombinant plasmids were cultured with vigorous aeration for $16 \mathrm{~h}$ at $37^{\circ} \mathrm{C}$ from a $1 \%(\mathrm{v} / \mathrm{v})$ inoculum in LB medium $(100 \mathrm{ml})$ containing ampicillin $\left(50 \mu \mathrm{g} \mathrm{ml}^{-1}\right)$. Cells were collected by centrifugation $\left(4000 \mathrm{~g}, 4^{\circ} \mathrm{C}, 10 \mathrm{~min}\right)$, washed once with ice-cold PC buffer ( $50 \mathrm{mM}-\mathrm{K}_{2} \mathrm{HPO}_{4}, 12 \mathrm{~mm}$-citric acid, $\mathrm{pH} 6.5$ ) and resuspended in the same buffer to a final volume of $4 \mathrm{ml}$. Cell suspension, cooled on ice, was ultrasonicated for 3 min (model W-225 ultrasonic processor; Heat SystemsUltrasonic Inc., Farmingdale, NY, USA; microtip; output control 7;50\% duty cycle) and then centrifuged for $30 \mathrm{~min}$ at up to $40000 \mathrm{~g}$ to remove debris. Cell-free extract was stored at $-20^{\circ} \mathrm{C}$.

Assay of endo- $\beta-1,4-$ glucanase activity. (i) Congo Red assay. Cellulase activity in $E$. coli $\mathrm{HB} 101$ transformants containing recombinant plasmids was assayed by means of the Congo Red plate assay, which is based on the strong interaction occurring between the dye Congo Red and polysaccharides containing more than six contiguous $\beta$-1,4-linked glucose residues (Teather \& Wood, 1982). Colonies cultured overnight at $37^{\circ} \mathrm{C}$ on LB with ampicillin $\left(50 \mu \mathrm{g} \mathrm{ml}^{-1}\right)$ were overlaid with PC buffer containing $0.5 \%$ (w/v) CMC (sodium salt; low viscosity; DS $>0.4$, $\mathrm{BDH})$ and $1 \%(\mathrm{w} / \mathrm{v})$ molten agar. After $3 \mathrm{~h}$ incubation at $60{ }^{\circ} \mathrm{C}$, plates were flooded with a $1 \%(\mathrm{w} / \mathrm{v})$ aqueous solution of Congo Red (Sigma) for $15 \mathrm{~min}$. Excess Congo Red solution was poured off and plates were washed with $1 \mathrm{M}-\mathrm{NaCl}$. CMCase ${ }^{+}$colonies were surrounded by a pale yellow halo or zone of clearing against a red background.

(ii) Viscometric assay. As a consequence of their mode of action, endoglucanases decrease the degree of polymerization of cellulosic substrates, causing a drop in viscosity. A rapid but nevertheless valid estimate of endoglucanase activity can therefore be obtained by measuring the time taken for a $50 \%$ reduction in the viscosity of $\mathrm{CMC}$ on incubation with the enzyme. Cell-free extract from $\mathrm{CMCase}^{+} E$. coli clones containing $1 \mathrm{mg}$ total protein was diluted to $0.25 \mathrm{ml}$ with $\mathrm{PC}$ buffer, and was incubated at $60^{\circ} \mathrm{C}$ with $16 \mathrm{ml}$ substrate solution containing CMC $(0.54 \%, w / v)$. Reaction was stopped by placing on ice or by boiling for $10 \mathrm{~min}$ and the efflux time was determined for the passage of the reaction mixture through a capillary-type viscometer (size $\mathrm{C}$; viscosity range, $6-$ $45 \mathrm{cS}$, Baird \& Tatlock). Specific viscosity ( $\eta$ ) was calculated as described by Schwarz et al. (1986). In place of enzyme, controls contained either water or cell-free extract from a $\mathrm{CMCase}^{-} E$. coli clone containing recombinant plasmid.

(iii) Reducing sugar assay. Samples $(4 \mathrm{ml})$ were removed from reaction mixtures set up for the viscometric assay and the reducing sugar present was measured colorimetrically using 3,5-dinitrosalicylic acid (Miller, 1959). Results were expressed as glucose equivalents, and in order to comply with other published work, one unit of 
enzyme activity was defined as that which released $1 \mu \mathrm{mol}$ glucose equivalent per hour from $\mathrm{CMC}$, under the assay conditions.

Assay of cellobiohydrolase and $\beta$-glucosidase activity. Cell-free extract $(50 \mu \mathrm{l})$ was added to $200 \mu \mathrm{l}$ PC buffer, $\mathrm{pH} 6.5$, containing 4-methylumbelliferyl $\beta$-D-cellobioside (MUC; $0.5 \mathrm{mg} \mathrm{ml}^{-1}$ ), a substrate held to be specific for cellobiohydrolase (Gilkes et al., 1984; Van Tilbeurgh et al., 1982), or 4-methylumbelliferyl $\beta$-D-glucoside (MUG; $0.5 \mathrm{mg} \mathrm{ml}^{-1}$ ). After $3 \mathrm{~h}$ incubation at $60^{\circ} \mathrm{C}$, a positive result was indicated by fluorescence under $\mathrm{UV}$ illumination at $310 \mathrm{~nm}$.

Thin-layer chromatography (TLC). Products formed from CMC incubated to completion in reaction mixtures described previously were fractionated by TLC on precoated silica-gel plates $\left(F_{254}\right.$; Merck) using chloroform/methanol/6 M-ammonia $(48: 60: 16$, by vol.) as developing solvent. To locate products, plates were sprayed with $50 \%(\mathrm{v} / \mathrm{v})$ sulphuric acid, followed by $10 \%(\mathrm{w} / \mathrm{v})$ resorcinol in acetone/water $(1: 1, \mathrm{v} / \mathrm{v})$ before heating at $160^{\circ} \mathrm{C}$ for $5 \mathrm{~min}$. Glucose and cellobiose standards (up to $25 \mu \mathrm{g}$ ) were run on each plate.

Partial purification of endoglucanases. Cell-free extracts were prepared as previously from cultures (up to 11 litres) of $\mathrm{CMCase}^{+} E$. coli clones in LB medium containing ampicillin $\left(50 \mu \mathrm{g} \mathrm{m}^{-1}\right)$. After heating at $60^{\circ} \mathrm{C} \mathrm{for} 3 \mathrm{~min}$, heat-agglutinated protein was removed by centrifugation $\left(2500 \mathrm{~g}, 4^{\circ} \mathrm{C}, 10 \mathrm{~min}\right)$ and $\left(\mathrm{NH}_{4}\right)_{2} \mathrm{SO}_{4}\left(0 \cdot 7 \mathrm{~g} \mathrm{ml}^{-1}\right)$ was added to the supernatant. Precipitated protein was dissolved in $200 \mathrm{~mm}$-phosphate buffer, pH 6.8 (20-30 ml), and applied to a column $(3.4 \times 150 \mathrm{~cm})$ of Sephacryl S-200, which was eluted with the same phosphate buffer. CMCase activity in column fractions was monitored by spotting samples $(12 \mu \mathrm{l})$ onto CMC agar films and incubating at $60^{\circ} \mathrm{C}$ for $30 \mathrm{~min}$ before staining with Congo Red as described previously. Active fractions producing a clear zone in the agar were combined and the protein was recovered by ammonium sulphate precipitation $\left(0.6 \mathrm{~g} \mathrm{ml}^{-1}\right)$ and centrifugation $\left(10000 \mathrm{~g}, 20^{\circ} \mathrm{C}, 10 \mathrm{~min}\right)$. Typically, CMCase activity emerged from the Sephacryl column after passage of 3 column volumes of elution buffer and had a 10-fold higher specific activity than the protein initially applied to the column. Partially purified proteins in the minimum volume of phosphate buffer were diluted with denaturing buffer and were subjected to sodium dodecyl sulphate-polyacrylamide gel electrophoresis (SDSPAGE) by the method of Laemmli (1970).

\section{RESULTS}

\section{Screening of libraries}

The two genomic libraries prepared by ligating the 4-9 kbp Sau3A fragments of $C$. thermocellum DNA into the BamHI site of plasmid pBR322 had an insertion rate of $>90 \%$. Five thousand $\mathrm{Ap}^{\mathrm{R}} \mathrm{Tc}^{\mathrm{S}}$ E. coli clones from the first library and 3000 clones from the second library were screened by means of the Congo Red plate assay and a total of $28 \mathrm{CMCase}^{+}$clones were recovered: RV1.1 to RV1.10 from the first library and RV2.1 to RV2.18 from the second. Plasmid was extracted from each $\mathrm{CMCase}^{+}$clone and it was confirmed that CMCase activity cotransformed with the $\mathrm{Ap}^{\mathrm{R}}$ character in E. coli $\mathrm{HB} 101$ with $100 \%$ frequency.

\section{Restriction enzyme mapping}

Recombinant plasmids extracted from each of the $28 \mathrm{CMCase}^{+}$clones were digested by BamHI, EcoRI, HindIII, PstI and SalI; no sites were found for the enzyme BglII. Analysis of the restriction data indicated that the 28 clones carried a total of 13 different DNA inserts. Cloned fragments occurring more than once were present in either identical or inverted orientation (Table 1). The sizes of the restriction fragments obtained by digesting the DNA insert of each of the 13 different recombinant plasmids with either EcoRI or HindIII are shown in Table 1 . The inserted DNA fragment varied in size from 3.0 to $12.8 \mathrm{kbp}$ but for 10 of the 13 unique clones fell within the range 4.0 to $5.6 \mathrm{kbp}$.

\section{Southern blot hybridization}

To establish that the different DNA inserts in $\mathrm{CMCase}^{+} E$. coli clones had been cloned intact and did not arise as a result of DNA rearrangements and deletions during cloning, ${ }^{32} \mathrm{P}$-labelled probes were prepared from each recombinant plasmid, including those cloned in duplicate, and were examined for hybridization with $C$. thermocellum chromosomal DNA which had been digested with BamHI, EcoRI, HindIII, PstI or SalI. With the exception of pRV2.4, the pattern of hybridization confirmed the physical map obtained for each insert (results not shown). According to restriction enzyme analysis, plasmid pRV2.4 was expected to hybridize with seven HindIII genomic fragments and three EcoRI fragments (Table 1). In reality hybridization took 


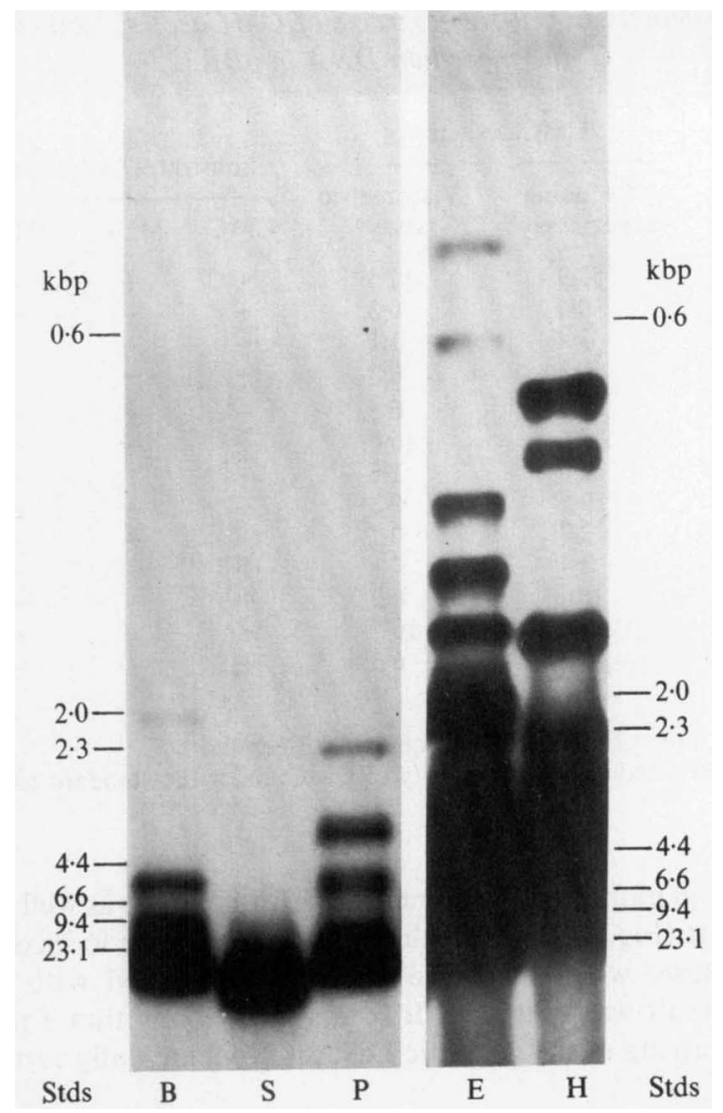

Fig. 1. Southern hybridization of ${ }^{32}$ P-labelled pRV2.4 with BamHI (B), SalI (S), PstI (P), EcoRI (E) and HindIII (H) digests of $C$. thermocellum chromosomal DNA. HindIII fragments of $\lambda$ phage DNA were run as standards (Stds) and the procedure was as described in Methods.

Table 1. Restriction enzyme analysis of the different cloned DNA fragments from CMCase ${ }^{+}$ $E$. coli clones containing $C$. thermocellum DNA in pBR322, and the duplication of CMCase ${ }^{+}$ clones in two genomic libraries

\begin{tabular}{|c|c|c|c|c|c|c|}
\hline \multirow[b]{2}{*}{ Plasmid } & \multirow[b]{2}{*}{$\begin{array}{l}\text { Size } \\
(\mathrm{kbp})\end{array}$} & \multirow[b]{2}{*}{$\begin{array}{l}\text { Insert } \\
\text { size } \\
(\mathrm{kbp})\end{array}$} & \multirow[b]{2}{*}{$\begin{array}{l}\text { Size of EcoRI } \\
\text { restriction fragments } \\
(\mathrm{kbp})\end{array}$} & \multirow[b]{2}{*}{$\begin{array}{l}\text { Size of HindIII } \\
\text { restriction fragments } \\
(\mathrm{kbp})\end{array}$} & \multicolumn{2}{|c|}{ No. of similar clones } \\
\hline & & & & & $\begin{array}{c}\text { Identical } \\
\text { orientation }\end{array}$ & $\begin{array}{c}\text { Inverted } \\
\text { orientation }\end{array}$ \\
\hline pRV1.1 & 8.7 & $4 \cdot 4$ & $1.9,1.9,0.5$ & $1 \cdot 8,1 \cdot 6,0 \cdot 7,0.3$ & 4 & 1 \\
\hline pRV1.5 & $8 \cdot 3$ & $4 \cdot 0$ & $2 \cdot 0,1 \cdot 1,0 \cdot 6,0 \cdot 3,0.05$ & $2 \cdot 4,1 \cdot 6$ & 4 & - \\
\hline pRV1.6 & $8 \cdot 3$ & $4 \cdot 0$ & & $3 \cdot 0,0.8,0.2$ & - & 1 \\
\hline pRV1.7 & $8 \cdot 3$ & $4 \cdot 0$ & $2 \cdot 8,1 \cdot 2$ & $2 \cdot 3,1 \cdot 4,0 \cdot 3$ & 2 & - \\
\hline pRV2.1 & 9.6 & $5 \cdot 3$ & $4 \cdot 5,0.8$ & $2 \cdot 7,2 \cdot 0,0 \cdot 6$ & - & - \\
\hline pRV2.2 & 9.8 & 5.5 & $4 \cdot 4,1 \cdot 1$ & $2 \cdot 2,2 \cdot 0,0 \cdot 7,0.5$ & 1 & - \\
\hline pRV2.3 & $17 \cdot 1$ & $12 \cdot 8$ & $7 \cdot 0,2 \cdot 1,1 \cdot 9,1 \cdot 5,0.6$ & $\begin{array}{r}4 \cdot 9,2 \cdot 4,2 \cdot 2,0 \cdot 8,0 \cdot 8 \\
0 \cdot 5,0 \cdot 4,0 \cdot 3,0 \cdot 25,0 \cdot 2\end{array}$ & - & - \\
\hline pRV2.4 & $9 \cdot 9$ & 5.6 & $4 \cdot 7,0 \cdot 4,0 \cdot 4,0 \cdot 1$ & $\begin{array}{l}1 \cdot 4,0 \cdot 8,0 \cdot 8,0 \cdot 75,0 \cdot 65 \\
0.6,0.6\end{array}$ & - & - \\
\hline pRV 2.5 & $9 \cdot 4$ & $5 \cdot 1$ & $4 \cdot 8,0 \cdot 3$ & $4.5,0.4,0.2$ & - & - \\
\hline pRV2.6 & $7 \cdot 3$ & $3 \cdot 0$ & $2 \cdot 7,0 \cdot 3$ & $1 \cdot 5,1 \cdot 3,0 \cdot 2$ & - & - \\
\hline pRV2.9 & 8.7 & $4 \cdot 4$ & & $3 \cdot 5,0.5,0.2$ & 1 & 1 \\
\hline pRV2.10 & $13 \cdot 2$ & 8.9 & $6 \cdot 5,1.9,0.5$ & $\begin{array}{l}5 \cdot 0,1 \cdot 4,1 \cdot 1,0 \cdot 7,0 \cdot 3 \\
0 \cdot 2,0 \cdot 2\end{array}$ & - & - \\
\hline pRV2.18 & $9 \cdot 2$ & $4 \cdot 9$ & $3 \cdot 8,1 \cdot 1$ & $2 \cdot 7,1 \cdot 9,0 \cdot 3$ & - & - \\
\hline
\end{tabular}


Table 2. Enzyme activity in cell-free extracts of $\mathrm{CMCase}^{+} \mathrm{E}$. coli clones containing C. thermocellum DNA in $P B R 322$

\begin{tabular}{lccccc} 
& \multicolumn{2}{c}{ CMCase activity } & \multicolumn{3}{c}{ Substrates hydrolysed } \\
\cline { 2 - 3 } Clone & $\begin{array}{c}\text { Reducing } \\
\text { sugar assay* }\end{array}$ & $\begin{array}{c}\text { Viscometric } \\
\text { assayt }\end{array}$ & $\overbrace{\text { CMC }}^{\text {MUC }}$ & MUG \\
RV1.1 & 53.9 & 12.5 & + & + & - \\
RV1.5 & 0.4 & 0.3 & + & - & - \\
RV1.6 & 3.4 & 1.1 & + & - & - \\
RV1.7 & 0.3 & 0.3 & + & - & - \\
RV2.1 & 1.7 & 0.5 & + & + & - \\
RV2.4 & 22.5 & 10.0 & + & + & - \\
RV2.18 & 2.0 & 1.6 & + & + & - \\
RV2.2 & 0.5 & 0.3 & + & - & - \\
RV2.3 & 2.7 & 0.7 & + & - & - \\
RV2.5 & 3.4 & 7.1 & + & - & - \\
RV2.6 & ND & 0.2 & + & - & - \\
RV2.9 & 60.6 & 16.7 & + & - & - \\
RV2.10 & 5.0 & 6.3 & + & - & -
\end{tabular}

ND, Not detected.

* Units (mg protein) $)^{-1}: 1$ unit $=1 \mu \mathrm{mol}$ glucose equivalent liberated $\mathrm{h}^{-1}$.

$\dagger 1 / t: t=$ time in $h$ for a $50 \%$ reduction in viscosity of CMC under the standard assay conditions.

place between the probe and multiple HindIII and EcoRI fragments, as well as with a number of BamHI and PstI fragments (Fig. 1). This result was clearly not due to incomplete digestion of chromosomal DNA because, when the same filter was re-probed with other recombinant plasmids, the predicted result was obtained. It seems more likely that a particular reiterated sequence or fragment occurring in the genomic DNA is coincidentally carried on the insert of pRV2.4.

Restriction enzyme analysis of the recombinant plasmids indicated that BamHI and SalI sites occurred less frequently than EcoRI and HindIII sites. This view was supported by the hybridization experiments which further showed that, in general, inserts contained in the $\mathrm{CMCase}^{+}$clones were part of very large BamHI and SalI chromosomal fragments.

By combining hybridization data with the previously determined sizes of restriction enzyme fragments, it was possible with certain clones to localize supplementary restriction sites on the chromosome adjacent to the cloned fragment, but there was no indication that any of the endoglucanase genes cloned in this work map close to each other.

Digestion of recombinant plasmid from CMCase ${ }^{+}$clones with HindIII resulted in the production of numerous apparently similar restriction fragments less than $1 \mathrm{kbp}$ in size. To determine whether these fragments were homologous, each recombinant plasmid was completely digested with $\mathrm{HindIII}$ and the fragments were fractionated on a $1 \%$ agarose gel and then transferred to Hybond N. ${ }^{32} \mathrm{P}$-labelled probes prepared from the $0.65,0.75$ and $0.8 \mathrm{kbp}$ HindIII fragments of pRV2.4 (Table 1) were used separately to probe each of the digested plasmids; hybridization occurred only between each fragment and the digest of the homologous insert. There was no evidence of homology with any of the other clones.

\section{Characteristics of $\mathrm{CMCase}^{+}$clones}

$\mathrm{CMCase}^{+}$clones differed with respect to the diameter of the halo produced on LB plates overlaid with CMC agar and stained with Congo Red; clones RV1.1, RV2.4 and RV2.9 produced large distinctive haloes with diameters of up to $10 \mathrm{~mm}$, while other clones produced smaller, but nevertheless very definite zones of clearing. $E$. coli $\mathrm{HB} 101$ had no detectable CMCase activity. Cell-free extracts prepared from $\mathrm{CMCase}^{+} E$. coli clones varied quite considerably in their ability to generate reducing sugar and reduce viscosity during the hydrolysis of CMC (Table 2). Under the assay conditions used, cell-free extract from the most 


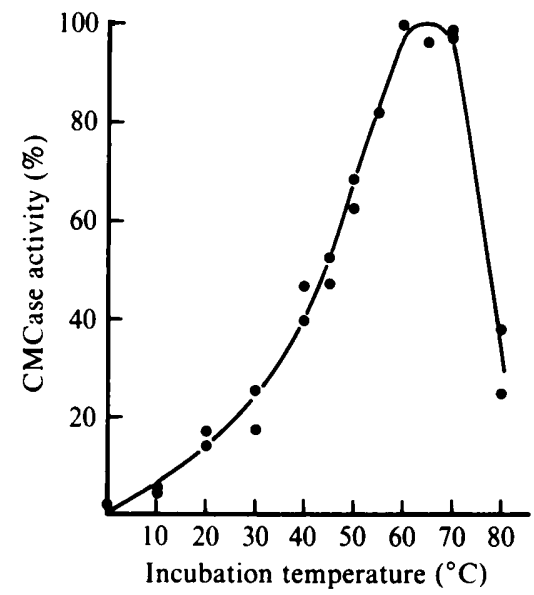

Fig. 2. Effect of temperature on CMCase activity of clone RV1.3. Viscometric assays were carried out as described in Methods, using $50 \mu \mathrm{g}$ cell-free extract protein for each incubation and CMC at $0.8 \%$ $(w / v)$. CMCase activity (initial rate of reduction of $\eta$ ) is expressed as a percentage of the activity at $60^{\circ} \mathrm{C}$.

active clones (RV1.1, RV2.4, RV2.9) produced reducing sugar rapidly and reduced the viscosity of $\mathrm{CMC}$ by $50 \%$ in $5 \mathrm{~min}$ or less; for these clones, change in specific viscosity $(\Delta \eta)$ per $\mu \mathrm{mol}$ glucose equivalent produced varied from 0.7 to 1.6 ; other less active clones attacked CMC more slowly but produced a similar reduction in viscosity per $\mu$ mol glucose equivalent. In contrast, extract from clones such as RV2.5 and RV2.10 reduced the viscosity of CMC by $50 \%$ in around $10 \mathrm{~min}$ without producing such large quantities of reducing sugar, and for these clones, $\Delta \eta$ per $\mu$ mol glucose equivalent produced varied from 4.6 to $7 \cdot 4$, indicating a different type of enzyme activity.

\section{Some properties of the enzyme activities expressed by clones RVI.1, RVI.5, RVI.6 and RVI.7}

Based on enzyme activity, the four different $\mathrm{CMCase}^{+}$clones of the first library that are listed in Table 2 appeared to be broadly representative of the two types of clone recovered from our libraries.

Analysis by TLC of the products formed from CMC by cell-free extracts prepared from these four clones revealed that the more active clone (RV1.1) produced glucose, cellobiose and longerchain-length cellulo-oligosaccharides and their carboxymethyl derivatives, while extract from the less active clones (RV1.5, RV1.6, RV1.7) produced only cellulo-oligosaccharides bigger than cellobiose from CMC.

Polypeptides retaining enzymic activity after complete or partial denaturation of the purified CMCase activity of each of the four clones were separated by SDS-PAGE and located on the gel by Congo Red staining of a CMC agar overlay (Beguin, 1983). The major endoglucanase activity of clone RV1.1 was stable after boiling in denaturing buffer, and had an apparent molecular mass of $78 \mathrm{kDa}$. The purified CMCase from clone RV1.5 was not stable on boiling, but retained activity after heating at $60^{\circ} \mathrm{C}$ in denaturing buffer and produced two major polypeptides with apparent molecular masses of 73 and $57 \mathrm{kDa}$. In contrast, CMCase activity purified from clones RV1.6 and RV1.7 was temperature labile, so these samples were applied to the gel in denaturing buffer without heating. Each of these clones produced a different pattern of three polypeptides with CMCase activity; for RV1.6 the molecular masses ranged from 55 to $90 \mathrm{kDa}$ and for RV1.7 the range was 80 to $90 \mathrm{kDa}$.

Using cell-free extract as source of enzyme and a saturating concentration of CMC, the effect of temperature on enzyme activity was determined for the endoglucanase expressed by clone RV1.3; this clone contained the same DNA insert and endoglucanase gene as RV1.1. Under our assay conditions, the rate of reduction of specific viscosity $(\eta)$ of the substrate was maximal around $65^{\circ} \mathrm{C}$, characteristic of a thermostable enzyme (Fig. 2). 


\section{DISCUSSION}

Biochemical analysis has shown the cellulosome of $C$. thermocellum to be composed of in excess of 14 polypeptides having endo- or exo-glucanase activity (Lamed et al., 1983a) and accordingly, one might expect the number of cel genes present on the genome to be high. It is therefore not particularly surprising that we, and another group (Millet et al., 1985), have found apparently different $\mathrm{CMCase}^{+}$clones with high frequency in genomic libraries prepared from the chromosomal DNA of this organism. In the present work, $\mathrm{CMCase}^{+}$clones occurred with varying frequency in two libraries constructed from Sau3A-digested DNA ligated into the BamHI site of plasmid pBR322. Although we have no information regarding the distribution of Sau3A sites in the DNA fragments encoding endoglucanase activity, it is possible that the higher frequency of occurrence of $\mathrm{CMCase}^{+}$clones in the second library (1 per 167 clones compared with 1 per 500 clones in the first) may be attributable to the very gentle manner in which the chromosomal DNA was partially digested.

The Congo Red assay, using CMC as substrate, does not select cellobiohydrolase-producing clones (Gilkes et al., 1984), so it seems likely that the 13 different DNA fragments cloned here bear genes encoding endoglucanase activity. The fact that cell-free extract prepared from each of the $\mathrm{CMCase}^{+}$clones liberated reducing sugar from $\mathrm{CMC}$ while significantly reducing its viscosity reinforces this view. However, variation in the ratio of the reduction in viscosity per $\mu$ mol reducing sugar liberated suggests that genes encoding different types of endoglucanase have been cloned. Thus, the more active clones such as RV1.1, RV2.4 and RV2.9 encode enzymes which liberate more reducing sugar per unit change in viscosity by cleaving bonds close to, as well as remote from, the ends of a chain and possibly in shorter chain-length cellulooligosaccharides also, while other clones such as RV2.5 and RV2.10 encode enzymes which cleave bonds remote from the chain ends, producing a more dramatic reduction in viscosity for each reducing end group liberated. Using clones obtained from the first library, limited TLC analysis of the products formed from CMC strengthens this view, in that the clone RV1.1 which has the $\mathrm{CMC}^{+} \mathrm{MUC}^{+}$phenotype, characteristic of both endoglucanase and exoglucanase activities, produced short- and long-chain cellulo-oligosaccharides and their carboxymethylated derivatives as well as glucose, while enzyme from clones RV1.5, RV1.6 and RV1.7 formed the long-chain products more characteristic of classical endoglucanase activity.

None of the clones described here had detectable $\beta$-glucosidase activity judging by their inability to hydrolyse MUG. Classification of the enzymes encoded by the 13 different DNA fragments as endoglucanases is slightly compromised by the ability which some have to attack MUC, a substrate thought to be specific for exoglucanase (Van Tilbeurgh et al., 1982). We take the view that, rather than indicating cellobiohydrolase activity, the $\mathrm{CMC}^{+} \mathrm{MUC}^{+}$phenotype is characteristic of certain endoglucanases with broad specificity which are able to cleave bonds close to the end of a CMC chain. This phenotype could result either from the production of two enzymes or, as has been previously suggested (Millet et al., 1985), from a single protein. In further unpublished work, we have shown that clone RV1.2, which is homologous with clone RV1.1 but carries a $2.4 \mathrm{kbp}$ DNA insert, has a promoter on a $0.5 \mathrm{kbp} E c o$ RI fragment. The remaining $1.9 \mathrm{kbp} E c o \mathrm{RI}$ fragment is probably only large enough to code for one complete protein and yet the clone expressed enzyme activity which, like that of clone RV1.1, hydrolysed both CMC and MUC. For other clones with the same phenotype but larger inserts, production of more than one enzyme cannot be ruled out. At present, there is a clear need for further biochemical characterization of the cloned cellulases of $C$. thermocellum, but available evidence suggests that they differ considerably from those described for the fungal system (Ljungdahl \& Eriksson, 1985).

Specific activity of CMCase was surprisingly high in cell-free extracts prepared from our most active clones (RV1.1, RV2.4, RV2.9), exceeding levels previously reported for three different $C$. thermocellum endoglucanases cloned in E. coli (Beguin et al., 1983; Cornet et al., 1983a; Petre et al., 1986; Schwarz et al., 1986) or bacteriophage $\lambda$ (Schwarz et al., 1986) and for endoglucanases from Bacteroides succinogenes (Crosby et al., 1984), Cellulomonas fimi (Gilkes et al., 1984) and Thermomonospora YX (Collmer \& Wilson, 1983) cloned and expressed in E. coli. Since $C$. 
thermocellum DNA is expressed well in $E$. coli, in some instances independently of orientation, differences in the CMCase activity of cell-free extract prepared under identical conditions from the same volume of $E$. coli culture may be attributable to the presence or absence of $C$. thermocellum regulatory sequences on the insert and the efficiency with which they function in E. coli. As an alternative, the high specific activity of our clones may be due in part to our assay procedure. The presence of substituents can affect the hydrolysis of adjacent linkages in CMC, so we have routinely used substrate with a low degree of substitution $(0.4)$ which is likely to give higher rates of hydrolysis than the more heavily substituted CMC used in at least one other study (Schwarz et al., 1986).

Restriction enzyme analysis showed that our original collection of $28 \mathrm{CMCase}^{+} E$. coli clones from two libraries contained 13 unique DNA inserts. With one exception, Southern hybridization with chromosomal DNA ratified the physical maps and confirmed that the inserts consisted of linear fragments cloned without deletions or rearrangements. The anomalous pattern of hybridization occurring between pRV2.4 and chromosomal DNA can be explained if a repeated sequence, such as might be associated with a transposon, is present in the insert of pRV2.4 and the chromosome ( $P$. Beguin, personal communication). Eleven of the 13 unique DNA inserts described here contained internal EcoRI sites. By virtue of the cloning approach adopted, celA, celB and five of the other previously cloned endoglucanase genes of $C$. thermocellum are borne on EcoRI fragments which have no internal EcoRI sites (Cornet et al., $1983 a$; Millet et al., 1985). Excluding the possibility that some cel genes may be reiterated with different flanking sequences, it seems likely that the DNA fragments we have cloned do not contain any of the cel genes previously cloned by the French group. With the exception of pRV2.9, which has some similarity with the celA coding region, this conclusion has been reinforced by comparison of detailed restriction maps (J.-P. Aubert, P. Beguin \& J. Millet, personal communication). $C$. thermocellum genes cloned in bacteriophage $\lambda$ included the cel $A$ gene and another uncharacterized endoglucanase gene (clone LIC 17) borne on a large insert which had numerous EcoRI and HindIII restriction sites (Schwarz et al., 1985). In the absence of detailed restriction maps or relevant hybridization data, it is impossible to conclude that this gene is absent from our inserts, but it may be significant that the proteins expressed by LIC 17 exhibited measurable activity against $p$-nitrophenyl $\beta$-D-glucoside, whereas our clones expressed no $\beta$-glucosidase activity.

In common with others (Millet et al., 1985) we have found that digestion of $C$. thermocellum DNA encoding CMCase activity with HindIII resulted in numerous fragments of similar size, suggesting the possibility of homology. However, three such fragments from pRV2.4 failed to hybridize with any of the fragments produced by HindIII digestion of each of the other 12 inserts, indicating that homology, if it exists, is quite low.

The effect of temperature on activity of the endoglucanase expressed by clone RV1.3 (homologous with RVl.1) confirms that the enzyme is thermostable and that this particular property is unchanged by expression in E. coli.

Loss of activity on boiling in the presence of SDS has been previously reported for some of the endoglucanases of $C$. thermocellum (Beguin, 1983). During this work, polypeptides obtained by SDS treatment of the endoglucanases from a representative sample of clones behaved differently on electrophoresis. SDS-PAGE of the completely denatured endoglucanase purified from clone RV1.1 indicated a molecular mass of $78 \mathrm{kDa}$ for the polypeptide produced. For clones RV1.5, RV1.6 and RV1.7 the appearance of more than one polypeptide band during electrophoresis could result from partial denaturation of protein, or from different gene products or from post-translational modification of a single protein, so values obtained for molecular mass should be treated with caution. Nevertheless, it is interesting that the apparent molecular masses of the constituent polypeptides of the cloned endoglucanases were within the size range reported for the partially denatured crude endoglucanases of $C$. thermocellum (Beguin, 1983).

Cloning and expression in $E$. coli of a further 13 apparently unique fragments of C. thermocellum DNA encoding CMCase activity brings the total of different endoglucanase genes reported to 21 . In the absence of gene reiteration, which has been suggested but not adequately demonstrated, and excluding the possibility that enzymically active components of 
the cellulosome have escaped detection, this confirms that the genome of $C$. thermocellum contains more $\mathrm{cel}$ genes than are apparently required.

The authors gratefully acknowledge the skilled technical assistance of Keith Davidson.

\section{REFERENCES}

BAYER, E. A. \& LAMED, R. (1986). Ultrastructure of the cell surface cellulosome of Clostridium thermocellum and its interaction with cellulose. Journal of Bacteriology 167, 828-836.

BeguIN, P. (1983). Detection of cellulase activity in gels using Congo Red-stained agar replicas. Analytical Biochemistry 131, 333-336.

Beguin, P., Cornet, P. \& Millet, J. (1983). Identification of the endoglucanase encoded by the $c e l B$ gene of Clostridium thermocellum. Biochimie 65, 495500 .

Beguin, P., Cornet, P. \& Aubert, J.-P. (1985). Sequence of a cellulase gene of the thermophilic bacterium Clostridium thermocellum. Journal of Bacteriology 162, 102-105.

Beguin, P., Rocancourt, M., Chebrou, M.-C. \& AUBERT, J.-P. (1986). Mapping of mRNA encoding endoglucanase A from Clostridium thermocellum. Molecular and General Genetics 202, 251-254.

BIRNBoim, H. C. \& Doly, J. (1979). A rapid alkaline extraction procedure for screening recombinant plasmid DNA. Nucleic Acids Research 7, 1513-1523.

Cohen, S. N., Chang, A. C. Y. \& Hso, L. (1973). Nonchromosomal antibiotic resistance in bacteria : genetic transformation of Escherichia coli by R-factor DNA. Proceedings of the National Academy of Sciences of the United States of America 70, 32403244.

Collmer, A. \& Wilson, D. B. (1983). Cloning and expression of a Thermomonospora YX endocellulase gene in Escherichia coli. Bio/Technology 1, 594-601.

Cornet, P., Millet, J., Beguin, P. \& Aubert, J.-P. (1983a). Characterization of two cel (cellulose degradation) genes of Clostridium thermocellum coding for endoglucanases. Bio/Technology 1, 589-594.

Cornet, P., Tronik, D., Millet, J. \& Aubert, J.-P. $(1983 b)$. Cloning and expression in Escherichia coli of Clostridium thermocellum genes coding for amino acid synthesis and cellulose hydrolysis. FEMS Microbiology Letters 16, 137-141.

Coughlan, M. P., Hon-Nami, K., Hon-Nami, H., Ljungdahl, L. G., Paulin, J. J. \& Rigsby, W. E. (1985). The cellulolytic enzyme complex of Clostridium thermocellum is very large. Biochemical and Biophysical Research Communications 130, 904-909.

Crosby, B., Collier, B., Thomas, D. Y., Teather, R. M. \& ERFLE, J. D. (1984). Cloning and expression in Escherichia coli of cellulase genes from Bacteroides succinogenes. In Fifth Canadian Bioenergy $R$ \& D Seminar, pp. 573-576. Edited by S. Hasnain. Amsterdam: Elsevier Applied Science Publications.

Gilkes, N. R., LANGSFORD, M. L., KilbuRn, D. E., Miller, R. C. \& WarRen, R. A. J. (1984). Mode of action and substrate specificities of cellulases from cloned bacterial genes. Journal of Biological Chemistry 259, 10455-10459.

GREPINET, O. \& BEgUiN, P. (1986). Sequence of the cellulase gene of Clostridium thermocellum coding for endoglucanase B. Nucleic Acids Research 14, 17911799.

Johnson, E. A., Sakajoh, M., Halliwell, G., Madia, A. \& Demain, A. L. (1982). Saccharification of complex cellulosic substrates by the cellulase system from Clostridium thermocellum. Applied and Environmental Microbiology 43, 1125-1132.

JolifF, G., Beguin, P. \& AUbert, J.-P. (1986a). Nucleotide sequence of the cellulase gene celD encoding endoglucanase D of Clostridium thermocellum. Nucleic Acids Research 14, 8605-8613.

Joliff, G., Beguin, P., JuY, M., Millet, J., Ryter, A., Poljak, R. \& Aubert, J.-P. (1986b). Isolation, crystallisation and properties of a new cellulase of Clostridium thermocellum overproduced in Escherichia coli. Bio/Technology 4, 896-900.

JolifF, G., Beguin, P., Millet, J., Aubert, J.-P., Alzari, P., JuY, M. \& Poljak, R. (1986c). Crystallization and preliminary $\mathrm{X}$-ray diffraction study of an endoglucanase from Clostridium thermocellum. Journal of Molecular Biology 189, 249-250.

LAEMMLI, U. K. (1970). Cleavage of structural proteins during the assembly of the head of bacteriophage T4. Nature, London 277, 680-685.

Lamed, P., Setter, E. \& Bayer, E. A. (1983a). Characterization of a cellulose-binding, cellulasecontaining complex in Clostridium thermocellum. Journal of Bacteriology 156, 828-836.

LAmed, R., Setter, E., Kenig, R. \& Bayer, E. A. $(1983 b)$. The cellulosome - a discrete cell surface organelle of Clostridium thermocellum which exhibits separate antigenic, cellulose-binding and various cellulolytic activities. Biotechnology \& Bioengineering Symposium 13, 163-181.

LJUNGDAHL, L. G. \& ERIKSSON, K. E. (1985). Ecology of microbial cellulose degradation. In Advances in Microbial Ecology, vol. 8, pp. 237-299. Edited by K. C. Marshall. New York \& London: Plenum Press.

Maniatis, T., Fritsch, E. F. \& Sambrook, J. (1982). Molecular Cloning: a Laboratory Manual. Cold Spring Harbor, NY: Cold Spring Harbor Laboratory.

MARMUR, J. (1961). A procedure for the isolation of deoxyribonucleic acid from micro-organisms. Journal of Molecular Biology 3, 208-218.

MilleR, G. L. (1959). Use of dinitrosalicylic acid reagent for determination of reducing sugar. Analytical Chemistry 31, 426-428.

Millet, J., Petre, D., Beguin, P., Raynaud, O. \& AUBERT, J.-P. (1985). Cloning of ten distinct DNA fragments of Clostridium thermocellum coding for cellulases. FEMS Microbiology Letters 29, 145-149.

NG, T. K. \& Zeikus, J. G. (1981). Purification and characterization of an endoglucanase $(1,4-\beta-D$ glucan glucanohydrolase) from Clostridium thermocellum. Biochemical Journal 199, 341-350.

Petre, D., Millet, J., Longin, R., Beguin, P., 
Girard, H. \& Aubert, J.-P. (1986). Purification and properties of the endoglucanase $C$ of Clostridium thermocellum produced in Escherichia coli. Biochemie 68, 687-695.

Petre, J., Longin, R. \& Millet, J. (1981). Purification and properties of an endo- $\beta$-1,4-glucanase from Clostridium thermocellum. Biochimie 63, 629-639.

Rigby, P. W. J., Dieckmann, M., Rhodes, C. \& Berg, P. (1977). Eabelling deoxyribonucleic acid to high specific activity in vitro by nick translation with DNA polymerase I. Journal of Molecular Biology 113, 237-251.

Schwarz, W. H., Bronnenmeier, K. \& StaudenBAUER, W. L. (1985). Molecular cloning of Clostridium thermocellum genes involved in $\beta$-glucan degradation in bacteriophage lambda. Biotechnology Letters 7, 859-864.

Schwarz, W. H., Grabnitz, G. \& Staudenbauer, W. L. (1986). Properties of a Clostridium thermocellum endoglucanase produced in Escherichia coli. Applied and Environmental Microbiology 51, 12931299.
SONNleitner, B. (1983). Biotechnology of thermophilic bacteria - growth products and application. In Advances in Biochemical Engineering/Biotechnology, vol. 28, pp. 69-138. Edited by A. Fiechter. Berlin: Springer-Verlag.

SOUTHERN, E. (1975). Detection of specific sequences among DNA fragments separated by gel electrophoresis. Journal of Molecular Biology 98, 503-517.

TEATHer, R. M. \& Wood, P. J. (1982). Use of Congo Red-polysaccharide interactions in enumeration and characterization of cellulolytic bacteria from the bovine rumen. Applied and Environmental Microbiology 43, 777-780.

Van Tilbeurgh, H., Claeyssens, M. \& de Bruyne, C. K. (1982). The use of 4-methylumbelliferyl and other chromophoric glycosides in the study of cellulolytic enzymes. FEBS Letters 149, 152-156.

WeIMER, P. J. \& ZeIKUS, J. G. (1977). Fermentation of cellulose and cellobiose by Clostridium thermocellum in the absence and presence of Methanobacterium thermoautotrophicum. Applied and Environmental Microbiology 33, 289-297. 